DOI https://doi.org/10.30525/978-9934-588-81-5-2.36

\title{
СТРУКТУРНІ КОМПОНЕНТИ ХРЕБЦІВ ГРУДНОГО ТА ПОПЕРЕКОВОГО ВІДДІЛІВ ЩУРА В НОРМІ
}

\author{
Паньків М. В. \\ аспірант кафедри нормальної анатомії \\ Львівський національний медичний університет імені Данила Галиџького \\ Пальтов Є. В. \\ кандидат медичних наук, \\ доцент завідувач електронною мікроскопією \\ Львівський наиіональний медичний університет імені Данила Галицького \\ Масна 3. 3. \\ доктор медичних наук, професор, \\ завідувач кафедри топографічної анатомії та оперативної хірургії \\ Львівський національний медичний університет імені Данила Галицького
}

Кривко Ю. Я.

доктор медичних наук, професор,

ректор

Львівська медична академія імені Андрея Крупинського

м. Львів, Украӥна

Вступ. Актуальність даної теми визначається тим, що у експериментальній морфології широко використовуються лабораторні тварини. Найбільш широко в експериментах представлені щури [1-4]. Існує ряд робіт в яких автори детально висвітлюють морфологічну норму різних органів щурів та зміни в органах при експериментально змодельованих патологічних станах [5-8]. У роботах деяких авторів присвячених питанням опорно - рухового апарату, дослідження хребтового стовпа щура $\epsilon$ недостатньо висвітленим. Тому метою нашої роботи $\epsilon$ вивчення будови структурних компонентів хребців грудного та поперекового відділу хребтового стовпа щура в нормі.

Вважаємо, що дане дослідження $є$ актуальним як з точки зору експериментального та морфологічного дослідження, так і $з$ практичної точки зору.

Матеріали та методи дослідження. Матеріалом дослідження слугували статево зрілі, безпородні щури - самці в кількості 15-ти тварин, масою 80 г, віком 4,5 місяців. Усі тварини знаходились в умовах віварію і робота, що стосувалася питань утримання, догляду, маркування та всі інші маніпуляції проводилися із дотриманням положень «Свропейської конвенції про захист хребетних тварин, які використовуються для експериментальних та інших наукових цілей» [Страз- 
бург, 1985], «Загальних етичних принципів експериментів на тваринах», ухвалених Першим Національним конгресом з біоєтики [Київ, 2001]. Закону України № 3447-IV «Про захист тварин від жорстокого поводження». Комісією з біоєтики Львівського національного медичного університету імені Данила Галицького встановлено, що проведені наукові дослідження відповідають етичним вимогам згідно наказу MO3 України № 231 від 01. 11. 2000 року (протокол № 10 від 26.12.2011 року), (протокол № 2 від 20 лютого 2012 року). Перед проведенням забору матеріалу тварин присипляли дибутиловим ефіром. Як матеріал для проведення макроанатомічного вивчення структурних компонентів хребців грудного та поперекового відділів використовували скелетизовані кістки щурів. Після евтаназії проводилося препарування хребтового стопа. Після проведених маніпуляцій хребці грудного та поперекового відділів хребтового стовпа підлягали виварюванню на протязі чотирьох годин з подальшим ретельним відокремлення рештків м'яких тканин. Отримані кістки оброблялися розчином перегідролю $з$ подальшим фотографуванням в різних проекціях 3 метою встановленням анатомічних елементів кожної, що беруть участь у формуванні в сукупності грудного та поперекового відділів. Фотографування препаратів здійснювали за допомогою цифрового фотоапарату Nicon D 3100.

Результати дослідження. У результаті проведеного дослідження використовуючи комплекс морфологічних методів, нами було встановлено ряд даних про структурні компоненти хребці нижнього грудного та поперекового відділів хребтового стовпа щурів в нормі. Хребтовий стовп щура складається із сукупності хребців, що формують його відділи. У хребтовому стовпі щура налічується 57 хребців. Шийний відділ представлений 7 хребцями, грудний 13, поперековий 6, крижовий 4 та хвостовий відділ у якому налічується 27 хребців.

Хребці грудного відділу - у щура налічується 12 вони мають тіло, дуги та відростки. Тіла грудних хребців щура мають призматичну форму і містять ямки для членування з ребрами. Ямка, що розташовується на тілі попереду лежачого хребця зчленовується з однойменною ямкою позаду лежачого хребця в результаті чого утворюється суглобова поверхня для щеленування з суглобовою поверхнею ребра. Дуги гребців грудного відділу складаються 3 двох половинок. На грудних хребцях добре виражені хребцеві вирізки. Як і в хребетному стовпі людини хребцеві вирізки беруть участь в утворенні між хребцевих отворів, що $\epsilon$ місцем виходу спинномозкового нерва. Від хребцевих дуг відгалужуються поперечні відростки в основі яких розташовуються суглобові відростки. На поверхні поперечних відростків чітко видно реберну ямку поперечного відростка, що слугує місцем для зчленування з горбком ребра. На грудних хребцях чітко видно остисті відростки. По мірі від- 
далення хребця від краніального напрямку до каудального остисті відростки стають більш плоскішими та масивнішими.

Хребці поперекового відділу - у щура налічується 6, у порівнянні 3 хребцями грудного відділу відрізняються більшою масивністю. Тіла хребців по мірі віддалення з краніального напрямку до каудального набувають більшої масивності. Серед анатомічних елементів у хребців поперекового відділу чітко вирізняються ямка хребця, головка хребця та сосцевидний відросток, що слугує апофізом для фіксації сухожилків. Особливістю остистих відростків хребців поперекового відділу є те, що вони плоскі та масивні а їх довжина збільшується при наближені до краніального напрямку і в подальшому знову зменшується.

Висновок:

В результаті проведеного нами дослідження було встановлено морфологію хребців грудного та поперекового відділів хребтового стовпа щура в нормі._Нами було вивчено набір морфологічних компонентів хребців грудного та поперекового відділів.

\section{Література:}

1. Онисько I.О., Маєвський О.С. Мікроструктурні зміни в язиці викликані впливом малих доз опіоїду протягом 70 і 84 діб (експериментальне дослідження). Український морфологічний альманах. 2013. Том 11. № 2. С. 72-76.

2. Онисько І.О., Король А.П., Маєвський О.С., Онисько Р.М. Зміни на електронномікроскопічному рівні в тканинах язика під впливом малих доз опіоїду в кінці 6 і 8 тижнів (експериментальне дослідження). Biomedical and Biosocial Antropology. 2013. № 2. С. 13-19.

3. Вільхова І.В. Морфологічні зміни ниркового тільця при дво-, чотири- та шеститижневому впливі налбуфіну (експериментальне дослідження). Український медичний альманах. 2014. Том 12. № 1. C. $13-16$.

4. Вільхова І.В. Патоморфологічні зміни ниркового тільця на пізніх термінах хронічного опіоїдного впливу). Журнал клінічних та експериментальних медичних досліджень. 2015. Том 3. № 1. С 25-31.

5. Якимів Н. Я., Кривко Ю. Я. Мікроструктурна характеристика райдужно-рогівкового кута очного яблука щурів при опіоїдному впливі. Світ медицини та біології. 2013. № 4. С. 120-124.

6. Підвальна У.С. Морфометрична характеристика перебудови судинної оболонки очного яблука під впливом налбуфіну. Український журнал Клінічної та лабораторної медицини. (Луганськ, 2013 р.). Луганськ, 2013. Т. 8. № 3. С. 94-97.

7. Paltov Y., Kryvko Y., Fik V., Vilkhova I., Ivasivka Kh., Pankiv M., Voitsenko K. Dynamics of the onset of pathological changes in the retinal layers at the end of the first week of opioid exposure. Deutscher Wissenschaftsherold. German Science Herald . 2016. Vol.2. 30-33 p. 
8. Paltov Y., Kryvko Y., Fik V., Vilkhova I., Ivasivka Kh., Pankiv M., Voitsenko K. Pathomorphological manifestations in the retina layers during one - week of opioid analgesic exposure. Natural Science Readings abstracts booc (Bratislava, May 19 - 22, 2016). Bratislava, 2016. 25-27 p.

DOI https://doi.org/10.30525/978-9934-588-81-5-2.37

\section{ГОРМОНАЛЬНА РЕГУЛЯЦІЯ ФЕТОПЛАЦЕНТАРНОГО КОМПЛЕКСУ ПРИ УСКЛАДНЕНІЙ ВАГІТНОСТІ}

\section{Селюкова Н. Ю.}

кандидат біологічних наук,

старший науковий співробітник відділу наукової роботи та патентно-лічензійної роботи

ДУ «Інститут проблем ендокринної патології імені В. Я. Данилевського

національної академії медичних наук України», асистент кафедри ветеринарної медицини та фармації

Начіональний фармацевтичний університет

\section{Коренсва С. М.}

кандидат біологічних наук, старший науковий співробітник

лабораторії репродуктивної ендокринологї

ДУ « Інститут проблем ендокринної патології імені В. Я. Данилевського Національної академії медичних наук України»

Морозенко Д. В.

доктор ветеринарних наук, завідуючий кафедрою ветеринарної медииини та фармації

Начіональний фармачевтичний університет

\section{Доценко Р. В.}

кандидат ветеринарних наук,

доцент кафедри ветеринарної медицини та фармаиіі

Начіональний фармачевтичний університет

Землянський А. $О$.

кандидат ветеринарних наук,

асистент кафедри ветеринарної медицини та фармащії

Національний фармацевтичний університет

м. Харків, Украӥна

Основними визначальними факторами здоров'я кожної дитини, крім генетичних факторів, $€$ іï особливості внутрішньоутробного 